Elżbieta Zastawnik

Zgromadzenie Sióstr św. Elżbiety

Węgierskiej, Prowincja Włoska
Kiedy myślimy Rodzina..., red. M. Duda,

K. Kutek-Sładek, Kraków 2016, s. 383-395

(Praca Socjalna w Teorii i Działaniu, 2).

\title{
Znaczenie bliskości rodziny podczas choroby
}

\author{
The importance of the proximity of the family \\ during illness
}

\begin{abstract}
The problem of the disease, directly or indirectly, affects every human being. Despite the development of many sciences that lend it to a thorough assessment, disease and suffering are for us largely a mystery. We observe that at a time when a person is faced with one of the many unknowns in life, what is a disease. This difficult moment of human existence makes that a man is faced with existential questions, including reflection on death. The issue not concerns only the sick people, but also members of their families. They must also confront their past life with a new, uneasy reality. Article draws attention to the role that
\end{abstract}

for the patient has contact with other people, especially with family members. By understanding the dificulty of these relationships, the author points to the need of building mutual understanding and taking in families uneasy dialogue of two worlds: the world of the disease and the world of healthy people. At the same time it points to the family as on the environment in shaping a proper attitude toward our neighbor, it also learn to overcome common difficulties and mutual responsibility.

Keywords: disease, health, family, mutual understanding, dialogue

We współczesnym świecie problem choroby i związanego z nim cierpienia, problem starości oraz niepełnosprawności są tematami wciąż aktualnymi, ale także w różnych aspektach wymagającymi ciągłych przemyśleń, stałych analiz oraz szukania nowych rozwiązań. Jest to konieczne, by człowiek, który ich do- 
znaje, dzięki wsparciu innych mógł godnie przeżyć ten trudny etap swojej egzystencji. W chorobie bowiem - jak mówi Katechizm Kościoła katolickiego ludzie doświadczają „swojej niemocy, ograniczeń i skończoności”. Równocześnie, nie mogąc do końca zrozumieć cierpienia, obawiają się go, co często jest przyczyną ich niepokoju, zamknięcia się w sobie, a także podłożem rozpaczy lub buntu przeciw Bogu². Ta kwestia dotyczy nie tylko ludzi dotkniętych chorobą, ale również ich rodzin, opiekunów i znajomych.

Celem artykułu jest ukazanie istoty kontaktu chorego z drugą osobą, zwłaszcza tą najbliższą. Obserwacja pokazuje bowiem, iż wielu ludzi doświadczonych ciężką, nieuleczalną lub przewlekłą chorobą obawia się utraty więzi z rodziną oraz z tymi, wśród których pracują i z którymi się przyjaźnią.

\section{Choroba a pojęcie zdrowia w kontekście rodziny}

Trudno byłoby znaleźć w świecie rodzinę, która nie byłaby doświadczona ciężarem choroby. Każdy bowiem człowiek doświadczył w jakiś sposób choroby, dlatego wie, jak ważna w tym czasie jest obecność kogoś bliskiego. Spróbujmy jednak na początku rozpatrzeć, czym jest choroba, by móc na tej podstawie określić, czym charakteryzuje się pojęcie zdrowia i zanalizować te pojęcia w kontekście rodziny.

Jerzy Strojnowski definiuje chorobę jako zaburzenie „wzajemnego oddziaływania środowiska zewnętrznego, narządów i tkanek, ograniczającego możliwości życiowe organizmu”’3. Według innych definicji jest ona dynamiczną reakcją organizmu na działanie czynnika chorobotwórczego ${ }^{4}$ oraz wyraża się nieprawidłowym współdziałaniem narządów i tkanek ${ }^{5}$. Jest więc stanem patologicznym zmiany funkcjonowania danego narządu lub całego cia$\mathrm{ła}^{6}$. Powyższe określenia wskazują, że choroba dotyczy nie tylko biologicznej sfery funkcjonowania człowieka. Ukazują ją one bowiem także w odniesieniu do sfery psychicznej, a co za tym idzie, również społecznej. Pokazują też

Katechizm Kościoła katolickiego, nr 1500, Poznań 1994.

Por. tamże, nr 1501.

3 J. Strojnowski, Choroba, [w:] Encyklopedia katolicka, t. 3, red. R. Łukaszyk, L. Bieńkowski, F. Lublin 1979, kol. 232-233.

4 Por. Choroba, [w:] Mała encyklopedia medycyny, t. 1, Warszawa 1987, s. 157.

5 Por. Choroba, [w:] Leksykon duchowości katolickiej, red. M. Chmielewski, LublinKraków 2002, s. 118.

6 Por. Malattia, [w:] N. Zingareli, Vocabolario della lingua italiana, Bologna 1988, s. 1087 . 
mechanizmy powstawania chorób oraz wzajemną współzależność czynników wewnątrzustrojowych człowieka i otaczającego go środowiska w procesie chorobotwórczym.

Światowa Organizacja Zdrowia (WHO) - jako obszar zmian występujących pod wpływem danego schorzenia - wskazuje jednocześnie na jego wymiar duchowy. Takie ujęcie choroby pozwala na zadanie pytania, czym jest zdrowie. Określa się je bowiem jako stan dobrego samopoczucia nie tylko cielesnego, ale również duchowego i społecznego ${ }^{7}$, „Zdrowie to nie tylko brak choroby, lecz pełny dobrostan jednostki w sensie biologicznym, psychicznym, społecznym”. Przez pojęcie zdrowia rozumiemy zatem „prawidłowe funkcjonowanie organizmu jako całości biologicznej" ${ }^{9}$, czyli dobry stan fizycznego i psychicznego samopoczucia człowieka będący wynikiem sprawnego funkcjonowania wszystkich jego narządów ${ }^{10}$.

W chwili dużego bólu człowiek przeważnie uważa, że nikt nie cierpi tak jak on i że to jego cierpienie jest największe. Taką reakcję można zaobserwować głównie w szpitalach, gdzie znajdują się ludzie chorzy. Zauważamy ją także $\mathrm{w}$ rodzinach, w których znajdują się ludzie chorzy lub starsi. Prawdziwy problem choroby w rodzinie zaczyna się jednak wtedy, gdy pojawia się w niej schorzenie przewlekłe lub nieuleczalne. Wtedy prędzej lub później dochodzi do konfrontacji dwóch światów: świata ludzi chorych i świata osób zdrowych. Trzeba jednak podkreślić, że w każdym środowisku - szpitalnym czy rodzinnym - człowiek potrzebuje drugiej osoby, ponieważ nie może realizować siebie oraz swojego człowieczeństwa w oderwaniu od innych. Stąd pojawia się potrzeba znalezienia właściwego obszaru porozumienia pomiędzy chorym lub chorymi a zdrowymi członkami rodziny. Na tej bowiem płaszczyźnie obie strony mogą w sobie rozwijać ludzkie wartości poprzez uznawanie swojej równości i godności oraz pielęgnowanie wzajemnego szacunku ${ }^{11}$. Zbudowana w taki sposób więź z innymi może sprawić, że chory człowiek zyska „nie tylko siłę, umiejętności i zdrowie, ale także zrozumienie, czym jest on sam"12.

Towarzyszenie osobie chorej wymaga niejednokrotnie od osób bliskich dużo odwagi, poświęcenia, czasami wręcz heroizmu. Zwykle, gdy ktoś zacho-

\footnotetext{
7 Podaję za H. D. Engelhardt, Umweltfaktoren und Krankheitsbedingungen, [w:] Handbuch der christlichen Ethik, t. II, Freiburg/B 1979, s. 79; por. J. Strojnowski, Zdrowie, [w:] Katolicyzm A-Z, red. Z. Pawlak, Poznań 1994, s. 401.

8 Podaję za B. Tobiasz-Adamczyk, Wybrane elementy socjologii zdrowia i choroby, Kraków 2000, s. 21.

$9 \quad$ B. Tobiasz-Adamczyk, Wybrane elementy socjologii zdrowia..., dz.cyt., s. 22.

10 Por. Salute, [w:] N. Zingarelli, Vocabolario..., dz. cyt., s. 1683.

11 Por. C. Van der Poel, W poszukiwaniu wartości ludzkich, Warszawa 1976, s. 47.

12 Tamże.
} 
ruje, staramy się zapewnić mu klimat ciepła, życzliwości i pełnej miłości obecności. Jednak w przypadku choroby przewlekłej lub nieuleczalnej, gdy choremu trzeba poświęcić coraz więcej czasu i uwagi, towarzyszenie mu staje się z dnia na dzień coraz trudniejsza i cięższa. Zdarza się więc, że osoby chore są marginalizowane przez swoje rodziny, a czasami wręcz przez nie porzucane. Czas cierpienia nie jest jednak tylko okresem próby, ale także szansą dla wszystkich członków wspólnoty rodzinnej. Realnie bowiem doświadczając, że „cierpienie i choroba są wpisane w tajemnicę życia człowieka na ziemi”'13, mają oni możliwość uczenia się podejścia do problemu choroby, starości, niepełnosprawności i wspólnego stawiania czoła trudnej codzienności.

\section{Wzajemne zrozumienie na płaszczyźnie rodzinnej}

Dzisiejszy świat często charakteryzuje się brakiem wyrozumiałości, zrozumienia i empatii. Zauważamy, iż obecnie coraz częściej obserwuje się „tendencję do lansowania cielesnego piękna, sprawności i wytrzymałości fizycznej; można wręcz powiedzieć promowania kulturystyki” ${ }^{14}$. Człowiek coraz częściej kieruje się dobrem własnym, co utrudnia mu zauważanie potrzeb bliźniego, nawet tego najbliższego. Spróbujmy zatem pokrótce zastanowić się, czym owo zrozumienie jest, by następnie móc skupić się nad jego wzajemną potrzebą zarówno ze strony rodziny, jak i osoby chorej.

Kiedy pytamy, czym dla kogoś jest zrozumienie, padają różne odpowiedzi. Dla jednych jest to umiejętność odczytywania znaków, które przekazuje druga osoba, dla drugich wrażliwość i życzliwość. Inni odpowiadają pytaniem: czy zrozumienie jest w ogóle możliwe? Artykuły encyklopedyczne pod hasłem „zrozumienie” podają, że jest ono umiejętnością rozumienia myśli i uczuć drugiego człowieka przy równoczesnym zdawaniu sobie sprawy z motywów i okoliczności jego działania. To także zdolność rozumienia i przenikania umysłem, tolerancja oraz łatwość rozważania z wyrozumiałością i/lub sympatią uczuć, opinii i działania innych. W ujęciu filozoficzno-logicznym natomiast „zrozumienie” określane jest jako zbiór elementów stanowiących jakąś myśl lub doktrynę, będącą równocześnie zrozumieniem koncepcji jej znaczeń, których może być

13 Jan Paweł II, Ewangelia cierpienia źródłem nadziei. Homilia podczas Jubileuszu Chorych i Pracowników Służby Zdrowia, Rzym, 11 lutego 2000 roku, „L'Osservatore Romano" (wyd. polskie) R. 21 (2000) nr 4 (222), s. 24.

14 E. Zastawnik, Apostolski wymiar choroby i cierpienia w życiu oraz nauczaniu Jana Pawła II, Kraków 2012, s. 9. 
tak wiele, jak bogate i obszerne jest znaczenie danego pojęcia ${ }^{15}$. Możemy zatem powiedzieć, że zrozumienie to posiadanie zarówno odpowiedniej wiedzy o czymś oraz umiejętność pojmowania tego czegoś, jak i życzliwość i wyrozumiałość wobec drugiej osoby, empatia, serdeczność oraz współczucie.

Jak można zauważyć na podstawie powyższych rozważań, fundamentem wzajemnego zrozumienia jest postawa otwartości wobec drugiej osoby. Nie można bowiem mówić o jakimkolwiek zrozumieniu, zwłaszcza w obrębie wspólnoty, jaką jest rodzina, bez szczerości oraz obopólnego, ustawicznego poznawania siebie i swoich reakcji, zwłaszcza podczas tak trudnego doświadczenia, jakim jest choroba.

Współczesny człowiek często boryka się z wieloma problemami natury egzystencjalnej. Chcąc przypodobać się innym, na siłę próbuje „wpasować się” w obowiązujące w danym środowisku ramy. W wyniku tego bardzo często przestaje być sobą, co powoduje, że staje się osobą zniewoloną, nieumiejącą wyzwolić się z życia bez strachu przed opinią innych oraz od przeświadczenia, że tylko wtedy będzie akceptowany, gdy będzie spełniał oczekiwania otaczających go ludzi. Ta sytuacja zmienia się w chwili choroby, zwłaszcza chronicznej lub nieuleczalnej. Stawia go ona bowiem w różnych, często nowych sytuacjach. Człowiek musi wtedy stanąć w prawdzie sam przed sobą i zdać sobie sprawę, że choroba, choć jest rodzajem nieszczęścia ludzkiego, jest także czymś, „dzięki czemu możemy dotrzeć do najgłębszej prawdy istnienia" ${ }^{16}$. Zmusza też do zastanowienia się nie tylko nad samym sobą, ale także nad sensem życia i refleksji nad śmier$\mathrm{cią}^{17}$. Choroba jest również czasem, gdy człowiek - bardziej lub mniej świadomie - szuka zrozumienia i akceptacji u drugiej osoby, zwłaszcza tej, która żyje najbliżej niego. Osiągnięcie tego będzie jednak możliwe wtedy, gdy wszyscy członkowie rodziny odkryją i zdadzą sobie sprawę, iż „, naturalną drogą do zrozumienia"18 jest droga miłości i ofiary ${ }^{19}$.

Zwrócił na to uwagę papież Jan Paweł II podczas Jubileuszu Roku 2000. Apelował wtedy do katolickich lekarzy, by okazywali „choremu pełną miłości troskliwość, wzorując się na ewangelicznym przykładzie dobrego Samary-

15 Por. Comprensiòne, [w:] New Times. Grande Enciclopedia Universale, vol. 4, red. M. Di Marco, Milano 1993, s. 2238; por. Comprensiòne, [w:] N. Zingarelli, Vocabolario..., dz. cyt., s. 414.

16 J. Tischner, Śmierć i słowo, [w:] Rozmowa z chorym, Kraków 1996, s. 9.

17 A. Kępiński, Melancholia, Kraków 2004, s. 36.

18 Jan Paweł II, Adhortacja apostolska Ojca Świętego Jana Pawła II o zadaniach rodziny chrześcijańskiej w świecie współczesnym Familiaris consortio, Rzym, 22 listopada 1981, nr 25, http://w2.vatican.va/content/john-paul-ii/pl/apost_exhortations/documents/hf_jp-ii _exh_19811122_familiaris-consortio.html (13.06.2015).

19 Por. tamże. 
tanina"20. Wezwanie to nie obejmuje jednak tylko lekarzy. Dotyczy ono nade wszystko członków rodziny oraz każdego, kto w sposób bezpośredni lub pośredni zaangażowany jest w szeroko rozumianą opiekę nad osobą chorą. Stąd tak ważne jest, aby zwłaszcza w rodzinie nie patrzeć na chorych przez pryzmat tego, co nas dzieli, ale kierować się ku temu, co może nas złączyć „we wzajemnym zrozumieniu i wzajemnym poszanowaniu praw każdego”21. Chęć poznania i zrozumienia nie może jednak oznaczać „wścibstwa i ciekawości”, ponieważ każdy człowiek ma prawo do prywatności i intymności.

\section{Rodzina miejscem budowania wzajemnego zrozumienia}

Poczucie braterskiej miłości, postawa otwartego serca, wrażliwość to elementy życia człowieka, których nie zdobywa się z dnia na dzień. Są one wypracowywane od najmłodszych lat w długotrwałym procesie wychowawczym, który rozpoczyna się w rodzinie. Rodzina bowiem stanowi podstawową komórkę społeczno-wychowawczą. Jest ona - jak podaje Józef Rembowski - „małą i jednocześnie pierwotną grupą o swoistej organizacji i określonym układzie ról między poszczególnymi członkami, związaną wzajemną odpowiedzialnością moralną, świadomą własnej odrębności, mającą swe tradycje i przyzwyczajenia, zespoloną miłością i akceptującą się nawzajem”22. Równocześnie jest wspólnotą, która w stosunku do swoich członków powinna spełniać określone funkcje, czyli dbać o zapewnienie odpowiednich środków egzystencji oraz uczyć i pokazywać, w jaki sposób te środki zdobyć. Powinna również troszczyć się o zapewnienie odpowiedniej pozycji społecznej i prestiżu, a także poprzez panujące wewnątrz niej stosunki - wskazywać na wartość obopólnej życzliwości i zrozumienia, a przez to przyczyniać się do nabywania umiejętności zespalania wszystkich członków rodziny ${ }^{23}$. Od tego, w jaki sposób rodzina funkcjonuje, co się w niej dzieje i na jakie wartości zwraca uwagę, zależeć więc będzie zachowanie dzieci i młodzieży nie tylko wewnątrz, ale i na zewnątrz rodziny. Relacje, jakie panują w konkretnej rodzinie, mają bowiem

20 Jan Paweł II, Medycyna a prawa człowieka. Przemówienie Ojca Świętego na Jubileusz lekarzy katolickich, Rzym, 7 lipca 2000 roku, „L'Osservatore Romano” (wyd. polskie) R. 20 (2000) nr 9 (996), s. 36.

21 Jan XXIII, Encyklika Ad Petri cathedram o rozwoju prawdy, jedności i pokoju w duchu miłości, Rzym, 29 czerwca 1959, nr II, http://w2.vatican.va/content/john-xxiii/it/encyc licals/documents/hf_j-xxiii_enc_29061959_ad-petri.html (13.06.2015).

22 J. Rembowski, Więzi uczuciowe w rodzinie, Warszawa 1972, s. 83.

23 Por. F. Adamski, Socjologia małżeństwa i rodziny, Warszawa 1982, s. 56. 
ogromny wpływ na późniejsze podejście młodego pokolenia do problemu choroby, starości, cierpienia i śmierci, a co za tym idzie, także do umiejętności rozumienia innych ludzi. Jak wynika z przedstawionych wcześniej określeń rodziny, powinna ona uczyć odpowiedzialności nie tylko za siebie, ale także za drugiego człowieka i przygotowywać go do dorosłego oraz odpowiedzialnego życia otwartego i skierowanego ku bliźniemu, także choremu. Od najmłodszych też lat powinna systematycznie wdrażać w wychowaniu młodych ludzi umiejętność porozumiewania się i kontaktu na płaszczyźnie „ja - chory lub starszy członek rodziny”. Gdy bowiem staną w dorosłym życiu w obliczu trudnych pytań dotyczących sensu życia, cierpienia i choroby, będzie im łatwej pobudzać nie tylko swoją, ale także i osoby dotkniętej chorobą nadzieję, która „pomoże [...] nadać nowy sens cierpieniu, przekształcając je w drogę zbawienia, w sposobność do ewangelizacji i do udziału w odkupieniu”24. Dlatego tak ważne jest, aby wychowywać młodych ludzi do szacunku dla innych oraz poszanowania zarówno ich dobra materialnego, jak i duchowego.

We współczesnym świecie obserwujemy coraz bardziej postępującą degradację życia rodzinnego. Przejawia się ona m.in. brakiem wzajemnego szacunku, poszanowania godności poszczególnych jej członków, zanikiem odpowiedzialności, brakiem wzajemnego zainteresowania ${ }^{25}$, odczłowieczeniem, depersonalizacją, umasowieniem, a czasem wręcz wykluczeniem danej osoby z rodzinnego kręgu. Niektórzy, nie umiejąc sobie poradzić z deklasacją, posuwają się do różnych form „ucieczki”, na przykład w narkomanię, alkoholizm, przemoc, agresję $e^{26}$ bądź w świat wirtualny. W odróżnieniu zatem od „zdrowej” rodziny, rodzina patologiczna nie jest w stanie zaspokoić podstawowych potrzeb dziecka, takich jak poczucie bezpieczeństwa, miłości lub naturalnej zależności. Nie jest też w stanie ukształtować pożądanych potrzeb społecznych, poznawczych oraz emocjonalnych, do których zaliczamy m.in. potrzebę uznania, samourzeczywistnienia, życzliwości bądź zaspokojenia ciekawości. Nie przekaże również odpowiednich norm społecznych i systemu wartości, jak również dorobku kulturowego społeczeństwa ${ }^{27}$.

Stąd też w czasach szerzącej się obojętności wobec drugiego człowieka oraz narastającego egoizmu, dbania wyłącznie o swój prywatny interes coraz bardziej istotna i ważna staje się konieczność kształtowania od najmłodszych lat sumie-

24 Jan Paweł II, Orędzie Jana Pawła II na VI Światowy Dzień Chorego 1998 roku, „L'Osservatore Romano" R. 18 (1997) nr 10 (196), s. 6.

25 Por. M. Ryś, Kształtowanie się poczucia własnej wartości i relacji z innymi w różnych systemach rodzinnych, „Fides et Ratio” (2011) nr 2 (6), s. 69-70.

26 Por. Jan Paweł II, Familiaris consortio, nr 43.

27 Por. O. Pokrzywnicka, Wpływ środowiska rodzinnego na rozwój psychiczny i społeczny dziecka, „Fides et Ratio” (2011) nr 2 (6), s. 42. 
nia oraz charakteru dziecka. Chodzi o to, by stawało się ono otwarte i wrażliwe na potrzeby innych i nie zatraciło świadomości winy pociągającej za sobą narastające poczucie względności norm moralnych ${ }^{28}$. Ów kryzys wartości „podważa tradycyjne struktury więzi społecznych, a wręcz doprowadza do ich rozpadu, od instytucji rodziny poczynając, i spycha na margines społeczeństwa chorych [...], często uważanych za ciężar dla rodziny i wspólnoty"29. Potrzeba zatem, aby młode pokolenie było tak formowane, by potrafiło stawiać czoło przyszłym trudnościom oraz ponosić ofiary dla realizacji późniejszych zadań ${ }^{30}$. Stąd konieczność wskazywania na destrukcyjną rolę, jaką w rozwoju życia odgrywa brak modlitwy, ofiary i pokuty, a także egoizm, oziębłość w relacjach z innymi oraz powierzchowność ${ }^{31}$. Trzeba zatem dołożyć wszelkich starań, aby na nowo odbudować rolę rodziny w życiu społecznym, tak aby była ona dla ogółu żywym przykładem „miłości, przebaczenia i wrażliwości”32.

\section{Dialog pomoca w odnajdywaniu właściwego nastawienia do choroby}

Katolicki moralista Bernard Häring napisał: „Nauka, historia, doświadczenie, cała mądrość ludzka wraz z Pismem Świętym stwierdzają, że człowiek jest czymś więcej niż izolowaną jednostką, czymś więcej niż monadą. Przez swą biochemiczną konstytucję, swą psychikę, duchowe tęsknoty i konkretną sytuację w życiu jest - i nie może tego uniknąć - zależnym i odpowiedzialnym członkiem jakiegoś ludu, rodziny"33. Każdy więc - pomimo swej choroby, cierpienia i słabości - by móc się rozwijać, potrzebuje kontaktu z innymi ludźmi. Podejmowany w ten sposób dialog prowadzi do poznania, poprzez które uczymy się rozumieć drugiego człowieka (tzw. poznanie rozumiejące), oraz do poznania, które może stanowić pewną formę współczucia (tzw. po-

28 Por. J. Orzeszyna, Społeczno-eklezjalny wymiar sakramentu pokuty, Kraków 1996, s. 231-232.

29 Benedykt XVI, Otaczajmy troska i miłościa umysłowo chorych, Orędzie na XIV Światowy Dzień Chorego 2006 r., [w:] W trosce o życie. Wybrane dokumenty Stolicy Apostolskiej, t. II, Tarnów 2012, s. 408.

30 Por. Jan XXIII, Encyklika Mater et Magistra o wspótczesnych przemianach społecznych $w$ świetle nauki chrześcijańskiej, nr 182, http://w2.vatican.va/content/john-xxiii/it/encyclicals/documents/hf_j-xxiii_enc_15051961_mater.html (17.06.2015).

31 Por. J. Orzeszyna, Społeczno-eklezjalny..., dz. cyt., s. 116.

32 Franciszek, Chrońcie największy skarb waszego kraju. Spotkanie z rodzinami w Manili, Manilia, 6 stycznia 2015, „L'Osservatore Romano” (wyd. polskie) R. 36 (2015) nr 2 (369), s. 19.

33 Moralność jest dla ludzi, Warszawa 1978, s. 73. 
znanie uczestniczące) ${ }^{34}$. By móc jednak mówić o podjęciu swoistego dialogu, jakim jest dialog świata choroby ze światem ludzi zdrowych - zwłaszcza we wspólnocie rodzinnej - owo poznanie powinno odbywać się na płaszczyźnie serca i szanować wartości ludzkie drugiej osoby. Umiejętność prowadzenia rozmowy będącej jedną ze składowych zarówno poznania rozumiejącego, jak i uczestniczącego, z jednej strony pozwala na poznanie tego, co przeżywa dana osoba, z drugiej daje możliwość współuczestniczenia w przeżywanym przez nią doświadczeniu. Co więcej, pozwala na zatrzymanie się i pochylenie nad cierpieniem i chorobą drugiej osoby oraz na wzięcie na siebie części „jej brzemienia i trudności, jakie [choroba] niesie ze sobą"35. Wypracowanie takiej postawy prowadzącej do solidarności z drugim człowiekiem wymaga jednak dużego wysiłku, wyrzeczenia oraz otwartości umysłu i serca. Jest ona nieodzowna w kontakcie z osobą chorą, starszą lub niepełnosprawną. Stąd tak ważne jest, aby zmagając się z problemem choroby w życiu osobistym lub u członka rodziny, umieć stanąć w obliczu postawionych przez Jana Pawła II pytań: „jaką miarą mierzyć człowieka? Czy mierzyć go miarą sił fizycznych, którymi dysponuje? Czy mierzyć go miarą zmysłów, które umożliwiają mu kontakt z zewnętrznym światem? Czy mierzyć go miarą inteligencji, która sprawdza się poprzez wielorakie testy czy egzaminy?"36. Wydaje się, że odpowiedzią na powyższe pytania jest stwierdzenie, iż jedyną właściwą miarą człowieka jest miara miłości. Miłość bowiem nie jest czymś abstrakcyjnym lub nierealistycznym, urojonym. Jest ona człowiekowi dana i równocześnie zadana, ponieważ z niej wypływa odpowiedzialność za drugiego człowieka. Podobnie jak miłość, jest ona naznaczona troską, jednak nie prowadzi do zubożenia lub zamknięcia człowieka, ale sprawia, że jest on bogatszy i bardziej otwarty. Dlatego im większe mamy poczucie odpowiedzialności za drugiego, tym więcej jest w nas prawdziwej miłości ${ }^{37}$.

Podczas jednego ze swoich przemówień w Roku Jubileuszowym Jan Paweł II dobitnie powiedział, że „Nie wolno «przechodzić obok» ludzi dotkniętych chorobą"38. To stwierdzenie Ojca Świętego dotyczy wszystkich ludzi, jednak najbardziej zobowiązuje rodzinę chorego. Postawa najbliższych wobec osoby chorej,

34 Por. J. Wal, Realizacja dobra wspólnego $w$ dialogu i poprzez dialog, „Warszawskie Studia Pastoralne" (2010) nr 12, s. 65.

35 Jan Paweł II, Ewangelia cierpienia źródłem..., dz. cyt., s. 24.

36 Jan Paweł II, Kazanie Ojca Świętego do młodzieży przy kościele św. Anny, Warszawa, 3 czerwca 1979, [w:] Jan Paweł II, Pielgrzymki do Ojczyzny 1979, 1983, 1987, 1991, 1995, 1997, 1999, 2002. Przemówienia, homilie, Kraków 2005, s. 27.

37 Por. K. Wojtyła, Miłość i odpowiedzialność, s. 84-85, http://fatimska.wloclawek.pl/ pliks/Karol\%20Wojtyla\%20-\%20Milosc\%20i\%20odpowiedzialnosc.pdf (20.06.2015).

38 Jan Paweł II, Ewangelia cierpienia źródłem..., dz. cyt., s. 24. 
wyrażana poprzez sposób zachowania wobec niej, ma ogromny wpływ na jej poczucie bezpieczeństwa i przekonanie o byciu potrzebną. Może także pomóc w akceptacji i przyjęciu trudnej rzeczywistości, jaką jest choroba, jak również w pogłębieniu swojego człowieczeństwa i duchowej przemianie.

\section{Rola chorych w rodzinie}

Zanim spróbujemy odpowiedzieć na pytanie: czy i jaką rolę spełniają osoby chore w rodzinie, zatrzymajmy się przez moment przy pojęciu inteligencji interpersonalnej oraz inteligencji intrapersonalnej. Pomogą nam one w lepszym uświadomieniu sobie, co implikuje naszą zdolność pokonywania problemów, przetwarzania informacji oraz zdobywania wiedzy, także przez szeroko rozumiane doświadczenie. Posłużą również do zrozumienia, co warunkuje umiejętność formułowania i wyrażania poglądów, wniosków i uczuć. Twórca definicji inteligencji wielorakich, Howard Gardner, inteligencję interpersonalną określa jako zdolność „dostrzegania różnic między innymi osobami, w szczególności różnic w ich nastrojach, temperamentach, motywacji i intuicjach" ${ }^{39}$, inteligencję intrapersonalną natomiast jako „wiedzę o wewnętrznych aspektach samego siebie, obejmującą dostęp do życia uczuciowego i odczuwanych przez siebie emocji oraz zdolność rozróżniania ich, określania i nazywania, a wreszcie zrozumienia na ich podstawie własnego zachowania i kierowania nim"40. Możemy zauważyć, iż sformułowania te korelują z podanymi wcześniej określeniami rodziny, a co za tym idzie - także z jej zadaniami. Kompatybilność ta wskazuje zatem, co zostało także wcześniej podkreślone, że rodzina stanowi podstawową komórkę, w której człowiek uczy się i nabywa zdolności społecznych. Zdefiniowane powyżej kompetencje, w odniesieniu do każdego członka rodziny, skierowane zarówno ad intra jak i ad extra, pozwolą na nawiązanie właściwych kontaktów międzyludzkich, opartych na wzajemnym zrozumieniu oraz umiejętności porozumiewania się i współczucia.

W obliczu choroby w rodzinie pojawiają się problemy spowodowane ludzką słabością. Każdy członek rodziny ma jednak w niej swoje określone zadania. Jest też na równi z innymi zobowiązany do odpowiedzialności za siebie nawzajem. Duże znaczenie będzie więc tu mieć odpowiedź na pytanie o motywację takiego czy innego postępowania. Wydaje się, że posiadane przez człowieka, także

39 H. Gardner, Inteligencje wielorakie. Nowe horyzonty w teorii i praktyce, http://www. edunews.pl/images/pdf/wstep_gardner.pdf, s. 29 (24.06.2015).

40 Tamże, s. 31 . 
chorego, możliwości bądź umiejętności konstruktywnego przezwyciężania trudności oraz wykorzystywania swoich mocnych stron będą pomocne w przygotowaniu się do nowych zadań w danej grupie społecznej - w naszym przypadku w rodzinie. Choroba sama w sobie nie wyklucza nikogo ze społeczeństwa, ale daje szansę na zmierzenie się z tym, co ze sobą niesie. Często podczas choroby dana osoba zmuszona jest do zmiany np. aktywności na polu zawodowym lub w kontaktach z innymi, a także w samej rodzinie. Potrzebuje zwiększonej uwagi, czasami wręcz pomocy w poruszaniu się i samej egzystencji. Taka sytuacja niewątpliwie wywołuje silny stres, którego wynikiem może być przygnębienie, poczucie zagrożenia, smutek, lęk, a nawet gniew. Obserwacja pokazuje jednak, że prócz tych negatywnych emocji, związanych z przeżywanym przykrym doświadczeniem, osoby chore odczuwają także wiele emocji pozytywnych. Widzimy u nich większą ochotę do działania, a nawet nadzieję ${ }^{41}$.

Wymienione powyżej stany emocjonalne oddziałują również na innych członków rodziny. Stąd ważne jest, aby wszyscy w duchu wzajemnej miłości i zrozumienia próbowali pomagać sobie nawzajem w radzeniu sobie w nowej rzeczywistości, przed którą zostali postawieni.

Jan Paweł II w Liście apostolskim Salvifici doloris napisał, że „cierpienie, które pod tylu różnymi postaciami obecne jest w naszym ludzkim świecie, jest w nim obecne także i po to, ażeby wyzwalać w człowieku miłość, ów właśnie bezinteresowny dar z własnego «ja» na rzecz innych ludzi, ludzi cierpiących" ${ }^{42}$. Chorzy nie mogą więc być usuwani na margines żadnej ludzkiej społeczności tym bardziej rodzinnej, ale jako w pełni wartościowa i cenna jej cząstka powinni być umieszczani w jej centrum. Bowiem poprzez swój przykład zmagania się z chorobą i cierpieniem pomagają innym zrozumieć podstawowe prawdy: między innymi o kruchości i przemijalności życia oraz o wartości wiary i nadziei chrześcijańskiej, na których powinno się budować ludzką egzystencję. Dlatego tak ważne jest, aby osoby chore nie „ukrywały się" za zasłoną swojego cierpienia, ale były dla swoich zdrowych bliskich przykładem znoszenia trudów codziennego zmagania się ze swoimi słabościami. Istotne jest również, by zdrowi potrafili otworzyć się i czerpać z tego swoistego „skarbca”, jakim są dla nich osoby doświadczone chorobąa ${ }^{43}$.

41 Por. A. Matczak, K. A. Knopp, Znaczenie inteligencji emocjonalnej $w$ funkcjonowaniu człowieka, Warszawa 2013, s. 172-173, http://www.liberilibri.pl/ksiazka/znaczenie-inte ligencji-emocjonalnej-w-funkcjonowaniu-cz\%C5\%82owieka. (20.06.2015).

42 Jan Paweł II, List apostolski o chrześcijańskim sensie ludzkiego cierpienia Salvifici doloris, Rzym, 11 lutego 1984, nr 29.

43 Por. Jan Paweł II, Niech waszym uniwersytetem będzie chory człowiek. Do Kapituły Zakonu Bonifratrów, 25 listopada 1988 roku [w:] Jan Paweł II, Modlitwy. Ewangelia cierpienia, Poznań 2005, s. 128. 
Podsumowując, należy podkreślić, że opisane podejście do problemu osoby chorej w rodzinie będzie dla niej szansą na umacnianie rodzinnych więzi ${ }^{44}$, a osoby chore staną się „wyrazicielami wspólnych ideałów i wartości, które są podstawą i regułą życia społecznego" ${ }^{45}$.

\section{Bibliografia}

Adamski F., Socjologia małżeństwa i rodziny, Warszawa 1982.

Benedykt XVI, Otaczajmy troska i miłościa umysłowo chorych. Orędzie na XIV Światowy

Dzień Chorego 2006, [w:] W trosce o życie. Wybrane dokumenty Stolicy Apostolskiej,

t. II, Tarnów 2012..

Choroba, [w:] Leksykon duchowości katolickiej, red. M. Chmielewski, Lublin-Kraków 2002.

Choroba, [w:] Mała encyklopedia medycyny, t. 1, Warszawa 1987.

Engelhardt H. D., Umweltfaktoren und Krankheitsbedingungen, [w:] Handbuch der christlichen Ethik, t. II, Freiburg/B 1979.

Franciszek, Lospedale più vicino, Audiencja generalna, Rzym, 10 czerwca 2015, „L'Osservatore Romano" (wyd. włoskie) R. 155 (2015) nr 130.

Franciszek, Chrońcie największy skarb waszego kraju. Spotkanie z rodzinami w Manili, Manilia, 6 stycznia 2015, „L'Osservatore Romano” (wyd. polskie), R. 36 (2015) nr 2 (369).

Gardner H., Inteligencje wielorakie. Nowe horyzonty w teorii i praktyce, http://www.edunews. pl/images/pdf/wstep_gardner.pdf, s. 29 (24.06.2015).

Jan Paweł II, List apostolski o chrześcijańskim sensie ludzkiego cierpienia Salvifici doloris, Rzym, 11 lutego 1984, nr 29.

Jan Paweł II, Kazanie Ojca Świętego do młodzieży przy kościele św. Anny, Warszawa, 3 czerwca 1979, [w:] tenże, Pielgrzymki do Ojczyzny 1979, 1983, 1987, 1991, 1995, 1997, 1999, 2002. Przemówienia homilie, Kraków 2005.

Jan Paweł II, Orędzie Jana Pawła II na VI Światowy Dzień Chorego 1998, „L'Osservatore Romano" R. 18 (1997) nr 10 (196).

Jan Paweł II, Medycyna a prawa człowieka. Przemówienie Ojca Świętego na Jubileusz lekarzy katolickich, Rzym, 7 lipca 2000 roku, „L'Osservatore Romano” (wyd. polskie) R. 20 (2000) nr 9 (996).

Jan Paweł II, Adhortacja apostolska Ojca Świętego Jana Pawła II o zadaniach rodziny chrześcijańskiej w świecie współczesnym Familiaris consortio, Rzym, 22 listopada 1981.

${ }_{44}$ Por. papież Franciszek, L’ospedale più vicino, Audiencja generalna, Rzym, 10 czerwca 2015, „L'Osservatore Romano” (wyd. włoskie) R. 155 (2015) nr 130, s. 8.

45 Jan Paweł II, List Ojca Świętego Jana Pawła II Do moich Braci i Sióstr - ludzi w podeszłym wieku, Watykan, 1 października (1999) nr 10. 
Jan Paweł II, Ewangelia cierpienia źródłem nadziei. Homilia podczas Jubileuszu Chorych i Pracowników Służby Zdrowia, Rzym, 11 lutego 2000 roku, „L’Osservatore Romano” (wyd. pol.) R. 21 (2000) nr 4 (222).

Jan XXIII, Encyklika Ad Petri cathedram o rozwoju prawdy, jedności i pokoju w duchu miłości, Rzym, 29 czerwca 1959, nr II, http://w2.vatican.va/content/john-xxiii/it/encycli cals/documents/hf_j-xxiii_enc_29061959_ad-petri.html (13.06.2015).

Jan XXIII, Encyklika Mater et Magistra, O współczesnych przemianach społecznych w świetle nauki chrześcijańskiej, 15 maja 1961, http://w2.vatican.va/content/john-xxiii/it/ encyclicals/documents/hf_j-xxiii_enc_15051961_mater.html (17.06.2015).

Katechizm Kościoła katolickiego, nr 1500, Poznań 1994.

Kępiński A., Melancholia, Kraków 2004.

Malattia, [w:] N. Zingarelli, Vocabolario della lingua italiana, ed. Zanichelli, Bologna 1988.

Matczak A., Knopp K. A., Znaczenie inteligencji emocjonalnej w funkcjonowaniu człowieka, Warszawa 2013, s. 172-173, http://www.liberilibri.pl/ksiazka/znaczenie-inteligencjiemocjonalnej-w-funkcjonowaniu-cz\%C5\%82owieka (20.06.2015).

Niech waszym uniwersytetem będzie chory człowiek. Do Kapituły Zakonu Bonifratrów, 25 listopada 1988, [w:] Jan Paweł II, Modlitwy. Ewangelia cierpienia, Poznań 2005.

Orzeszyna J., Społeczno-eklezjalny wymiar sakramentu pokuty, Kraków 1996.

Pokrzywnicka O., Wplyw środowiska rodzinnego na rozwój psychiczny i społeczny dziecka, „Fides et Ratio” (2011) nr 2 (6).

Rembowski J., Więzi uczuciowe w rodzinie, Warszawa 1972.

Ryś M., Kształtowanie się poczucia własnej wartości i relacji z innymi w różnych systemach rodzinnych, „Fides et Ratio” (2011) nr 2 (6).

Strojnowski J., Zdrowie [w:] Katolicyzm A-Z, red. Z. Pawlak, Poznań 1994.

Tischner J., Śmierć i słowo, [w:] Rozmowa z chorym, Kraków 1996.

Tobiasz-Adamczyk B., Wybrane elementy socjologii zdrowia i choroby, Kraków 2000.

Wal J., Realizacja dobra wspólnego w dialogu i poprzez dialog, „Warszawskie Studia Pastoralne” (2010) nr 12, s. 60-75.

Poel C., van der, W poszukiwaniu wartości ludzkich, Warszawa 1976.

Strojnowski J., Choroba, [w:] Encyklopedia katolicka, t. 3, Lublin 1979, kol. 232-233.

Wojtyła K., Miłość i odpowiedzialność, http://fatimska.wloclawek.pl/pliks/Karol\%20Wojtyla\% 20-\%20Milosc\%20i\%20odpowiedzialnosc.pdf (20.06.2015).

Zastawnik E., Apostolski wymiar choroby i cierpienia w życiu oraz nauczaniu Jana Pawła II, Kraków 2012. 
A. Uniwersytet Papieski T.5. Jana Pawła II 